\title{
Impact of Six Sigma in a developing economy: analysis on benefits drawn by Indian industries
}

\author{
Darshak A. Desai ${ }^{1}$, Mulchand B. Patel ${ }^{2}$ \\ ${ }^{1}$ G. H. Patel College of Engineering \& Technology, Vallabh Vidyanagar (INDIA); \\ ${ }^{2}$ Government Engineering College, Shamlaji Road, Modasa (INDLA) \\ darshak301@yahoo.com; mulchandbhaichand@yahoo.com
}

Received September 2009

Accepted December 2009

\begin{abstract}
Overall operational excellence is the key requirement of any business to have global competence and sustained growth. Indian industries are not the exception to this. Six Sigma has emerged as one of the most effective business improvement strategies worldwide. Nothing much has been published so far illustrating an overall experience of Indian industries with Six Sigma. This paper presents an analysis of the impact of Six Sigma on developing economy like India. The paper provides an insight into what kind of benefits Indian industries are gaining from Six Sigma as a whole. The study further highlights similarity and differences of benefit gained by different scales and sectors of Indian industries through Six Sigma. This exhaustive analysis of the benefits drawn by Indian industries through Six Sigma can assist other industries in India as well as those in other developing countries, who have yet not experimented with Six Sigma, to become more focused regarding their expectations from this improvement drive.
\end{abstract}

Keywords: Six Sigma, Indian industries, benefits, impact, developing economy

\section{Introduction}

Six Sigma has emerged as one of the most effective business improvement strategies over the years. This quantitative approach aims at improving efficiency 
and effectiveness of the organization. It is the methodology having statistical base focusing on removing causes of variations or defects in the product or core business processes. The improvement focus is on business outputs which are of critical importance to the customers. In the current dynamic industrial scenario, quality alone is not the wining criteria; consistent supply of quality goods as per the committed delivery schedules makes the customers happy. Six Sigma methodology addresses the major root causes and guarantees the targeted results, both in terms of improvements desired and time span fixed. It is a disciplined, data-driven approach and methodology for eliminating defects in any process from manufacturing to transactional, from products to services. This breakthrough improvement strategy delivers results of productivity, profitability and quality improvements based on its highly effective approach (Desai, 2008).

From the researches and surveys conducted and published so far, it appears that Six Sigma is not being explored by the developing economies to its full potential and Indian is not an exception in this. Indian industries have experienced periodic impacts of transformation, both, before and after industrial reforms. Initially, the focus was on large-scale public and private sectors, mainly in the core infrastructural production. The main thrust was on productivity based on Taylor's principles of Scientific Management. After globalization and liberalization, quality surfaced as one of the major area of concern along with productivity. With opening up of the geographical barriers and the pressure of competing in the global market, overall operational excellence becomes the necessity for the Indian industries to remain globally competitive. Many Indian industries have successfully exploited this breakthrough business improvement strategy to their overall benefits. Still the penetration Six Sigma in Indian industries is not as encouraging as it should be. There are certain issues preventing the full use of Six Sigma as an overall business improvement strategy by Indian industries. And there are certain advantages too for Indian industries, which can be further strengthened to have an edge in the global market by effectively utilizing Six Sigma strategy.

This paper illustrates the results obtained from a cross-sectional study of the benefits obtained by entire Indian industries as a whole by implementing Six Sigma in their organizations. The paper also discusses the similarity or otherwise in fetching the benefits from Six Sigma programme by different size and sector of Indian industries. The basic objective of this research study is to highlight the spectrum of benefits the Indian industries could achieve by Six Sigma and thus to 
encourage other industries who have yet not attempted Six Sigma for the breakthrough improvements.

\section{Six Sigma - A brief overview}

As per Park (2002) Six Sigma implies three things: statistical measurement, management strategy and quality culture. It tells us how good products, services and processes really are, through statistical measuring of quality level. It is new management strategy under leadership of the top management to create quality innovation and total customer satisfaction. It is also a quality culture. It provides the way to do things right the first time and to work smarter by using data information. Antony, Kumar and Madu (2005) stated that Six Sigma provides business leaders and executives with the strategy, methods, tools and techniques to change their organizations. As per them, there are four aspects of the Six Sigma strategy that are not emphasized in other business improvement methodologies and total quality management (TQM). First of all, Six Sigma places a clear focus on bottom-line savings. Second, Six Sigma has been very successful in integrating both human aspects (culture change, training, customer focus etc.) and process aspects (process stability, variation reduction, capability etc.) of continuous improvement. Third, Six Sigma methodology (DMAIC) links the tools and techniques in a sequential manner. Finally, Six Sigma creates a powerful infrastructure for training of champions, master black belts, black belts, green belts, and yellow belts. As per Voelkel (2002) the business-oriented definition of Six Sigma states that it blends correct management, financial and methodological elements to make improvement to process and products in ways that surpass other approaches. While as per Magnusson, Kroslid and Bergman (2003) Six Sigma is a business process that allows companies to drastically improve their bottom line by designing and monitoring everyday business activities in ways that minimize waste and resources while increasing customer satisfaction by some of its proponents. Linderman, Schroeder, Zaheer and Choo (2003) in defining Six Sigma stress up on process improvement and new product development by stating that Six Sigma is an organized and systematic method for strategic process improvement and new product and service development that relies on statistical methods and the scientific method to make dramatic reductions in customer defined defect rates.

In statistical terms, Sigma $(\sigma)$, as we know, is a letter in the Greek alphabet that has become the statistical symbol and metric of process variation. The sigma scale 
of measure is perfectly correlated to such characteristics as defects-per-unit, partsper-million defectives, and the probability of a failure. Six is the number of sigma measured in a process, when the variation around the target is such that only 3.4 outputs out of one million are defects under the assumption that the process average may drift over the long term by as much as 1.5 standard deviations. The technical concept of Six Sigma is to measure current performance and to determine how many sigmas exist that can be measured from the current average until customer dissatisfaction occur. When customer dissatisfaction occurs, a defect results (Eckes, 2001).

Further, Franken (2007) highlighted that if its internal operations are not well structured, a company will find it difficult to create value and be highly competitive. Six Sigma began as a focus on improving internal operations. The methodology is targeted on the processes within an organization. Of course, it is better to build in excellence when business processes are first being developed and designed, but often operational processes have to be improved to be made excellent afterward. Six Sigma and its tools are not limited to production processes. Sales, marketing and research and development departments also are filled with processes that can be improved. While a company might have a natural competitive advantage because its competitors have such poor products or sales efforts, in today's marketplace this is unlikely. Therefore, organizations need to excel in all areas. Companies that use Six Sigma are striving for operational excellence. Six Sigma is a data-driven, structured, $\mathrm{Cl}$ programme that works at a company's foundation to help it reach operational excellence. Operational excellence is the goal - Six Sigma is a means to that goal.

The Six Sigma methodology DMAIC offers a structured and disciplined process for solving business problems. Six Sigma uses tools designed to identify root causes for the defects in processes that keep an organization from providing its customers with the consistent quality of products the customers require on time and at the most reasonable cost. The Six Sigma work is normally done through cross-function teams that manage the project (Zucker, 2007).

The essence of Six Sigma is found in the reality that business processes are inherently unpredictable. Six Sigma provides a way of measuring the variability in a process as it delivers services to an end-user or customer. When most people talk about Six Sigma, they are thinking about the DMAIC methodology. This 
method is used for improving an existing process when it is not meeting customer needs (Carey, 2007). Six Sigma is a holistic approach to achieving near perfection, expressed in terms of no more than 3.4 errors per million opportunities. This near perfection appears too many to be overkill or to some, an impossible ideal. Nonetheless, Six Sigma has been adopted by many leading companies. The benefits are well documented for manufacturing industries and increasingly, in service industries (Wright \& Basu, 2008).

\section{Six Sigma in Indian industries}

Six Sigma has been utilized considerably by Indian industries during last decade. Especially large concerns have successfully tried this breakthrough improvement strategy to get solutions in many of their chronic problems. But small and medium enterprises are still ignorant regarding strengths of this improvement drive, of course there may be few exceptions. Sparing some sporadic articles and case studies in the corporate publications and magazines, the research publications illustrating wide-ranging studies regarding penetration of Six Sigma among Indian industries as a whole are not available so far.

Specific case illustrations are there discussing successful application of Six Sigma at small and medium sized Indian industries (Desai, 2008, 2006). But an exhaustive analysis of the experience of different size and sectors of Indian industries with Six Sigma is not available in research publications.

Some studies targeting on quality engineering and management scenario in Indian industries as a whole did provided a glimpse on status of Six Sigma in Indian industries. But that is not enough to draw a comprehensive conclusion regarding experience of Indian industries with Six Sigma as a whole (Khanna, Vrat, Sahay, \& Shankar, 2002; Kumar, Garg, \& Mehta, 2002).

\section{Research objectives and methodology}

The basic objective of this study was to explore the benefits drawn by Indian industries as a whole by implementing Six Sigma improvement drive at their organizations. To make the study exhaustive, entire spectrum of Indian industries were considered as population for the study. Thus, a specific questionnaire was sent out to all size and type of the Indian industries. 
The specific objectives of the study are listed as below.

- To know the overall benefits drawn by Indian industries as a whole by implementing Six Sigma.

- To find out whether Six Sigma is bringing similar benefits to large as well as small and medium sized Indian industries.

- To find out whether Six Sigma is bringing similar benefits to different sectors of Indian industries.

- To know the benefiting criteria of Six Sigma implementation where large as well as small and medium scale Indian industries have similar and totally different experiences.

- To know the benefiting criteria of Six Sigma implementation where different sectors of Indian industries have similar as well as totally different experiences.

As learnt in the previous section that wide-ranging research study exploring the implications of Six Sigma implementation in Indian industries as a whole is not available so far, the objectives are framed accordingly to cover complete crosssection of Indian industries. The first objective signifies the overall impact of Six Sigma in Indian industries as a whole. This is the macro illustration of benefits reaped by Indian industries by implementing Six Sigma. The second and third objectives combined dig into the micro details of impact of Six Sigma in different size and sectors of Indian industries. These two objectives of the study explore the experiences of different sizes of the industries as well as different sectors, such as manufacturing, services, IT etc. This can uncover the strength of Six Sigma improvement strategy to bring similar benefits irrespective of the size and type of the industries. The last two objectives though appear as redundant with respect to the results expected from second and third objectives; they are there to provide further detailing on the specific benefiting criteria where different sizes and sectors of Indian industries have gained similar or totally different benefits from Six Sigma. They provide insight into size and sector specific benefits of Six Sigma implementation. 
The overall significance of above research objectives will help both, academic as well as industrial community. The study can generate sizeable data base on implications of Six Sigma among Indian industries. These data can further be analyzed for academic purpose to augment Six Sigma principles and practices. Industrial population can use the results of this study to understand the Six Sigma in better way and can customize the benefits of its implementation based on their respective size and type of operation.

\subsection{Population and samples}

To make the study exhaustive entire Indian industries were considered as population of the research study. For sampling general stratification was done with an aim to include samples from all the types, capacities and sectors of the Indian industries. As such In India, the small and medium enterprises are not well defined. The internal group set up by the Reserve Bank of India has recently recommended that the units with investment in plant and machinery in excess of Small scale industries (SSI) limit and up to Rs. 100 million may be treated as medium enterprises (EXIM Bank, 2005). In India, the cut off investment limit for defining a SSI at present is Rs.10 million (Verma, 2005).

\begin{tabular}{|c|l|c|}
\hline Sr. No. & Benefiting Criteria & $\begin{array}{c}\text { Mean } \\
\text { Score }\end{array}$ \\
\hline 1 & Reduction of scrap rate & 3.364 \\
\hline 2 & Reduction of cycle time & 3.455 \\
\hline 3 & Reduction of delivery time & 3.273 \\
\hline 4 & Reduction of customer complaints & 3.455 \\
\hline 5 & Increase in productivity & 3.273 \\
\hline 6 & Reduction of variability of process & 3.636 \\
\hline 7 & Reduced need for checking/inspection & 3.273 \\
\hline 8 & Reduction of costs & 3.818 \\
\hline 9 & Increase in profitability & 3.545 \\
\hline 10 & Improved sales & 3.273 \\
\hline 11 & Improvement in company image & 3.000 \\
\hline 12 & Improvement in employees morale & 2.909 \\
\hline 13 & Increase in overseas sales & 2.636 \\
\hline 14 & New product development & 3.000 \\
\hline 15 & Entry into new markets & 2.455 \\
\hline 16 & $\begin{array}{l}\text { Improved attitude of employees towards quality and } \\
\text { problem solving }\end{array}$ & 3.000 \\
\hline 17 & $\begin{array}{l}\text { Improved attitude of top management towards quality } \\
\text { and problem solving }\end{array}$ & 3.273 \\
\hline
\end{tabular}

(Scale: $1=$ no benefit, 2 = some benefit, $3=$ significant benefit, $4=$ very significant benefit and $5=$ crucial benefit)

Table 1. "Benefits of Six Sigma programme to Indian industries - General Observations". 
A comprehensive survey questionnaire was prepared covering total 17 key benefiting criteria of Six Sigma implementation as listed in table 1 . The respondents were asked to indicate their size and sector in the questionnaire so as to group them accordingly. The respondents were asked to rate each criteria with respect to their experience of benefits gained from Six Sigma programme in the scale of 1 to 5 ( 1 = no benefit, $2=$ some benefit, $3=$ significant benefit, $4=$ very significant benefit and $5=$ crucial benefit). The questionnaire was sent out to all variety of industries across the country. The companies were randomly selected covering different sectors and size. The questionnaire was sent to 600 concerns across the country and the valid rate of response was around $16 \%$ which is considered as fairly good enough. The data were then tested for normality and found suitable for further statistical analysis.

\subsection{Methodology}

The responses obtained were analyzed in general as well as in specific and detail for different sizes and sectors of Indian industries. The preliminary analysis contains the average ranking of all the benefiting criteria as experienced by the Indian industries as a whole.

To get detailed insight separate analysis were made for the different size as well as sectors of the Indian industries. The data were examined through one way ANOVA as well as Chi-square analysis for similarities or otherwise in these two separate categories, that is scale and sector of Indian industries. One -way ANOVA was selected here because unlike t-test, which uses sample standard deviations, ANOVA uses squared deviations of the variance so computations of distances of the individual data points from their own mean or from the grand mean can be summed. In ANOVA model, each group has its own mean and values that deviates from that mean. Similarly, all the data points from all of the groups produce an overall grand mean. To be precise, the total deviation of any particular data point can be partitioned into between - group variance and within - group variance. 


\section{Results and analysis}

\subsection{Industry responses}

Figure 1 illustrates the response rate of the different size of the Indian industries. It is evident from the figure that large scale industries where Six Sigma is implemented are greater in number compared to medium scale enterprises.

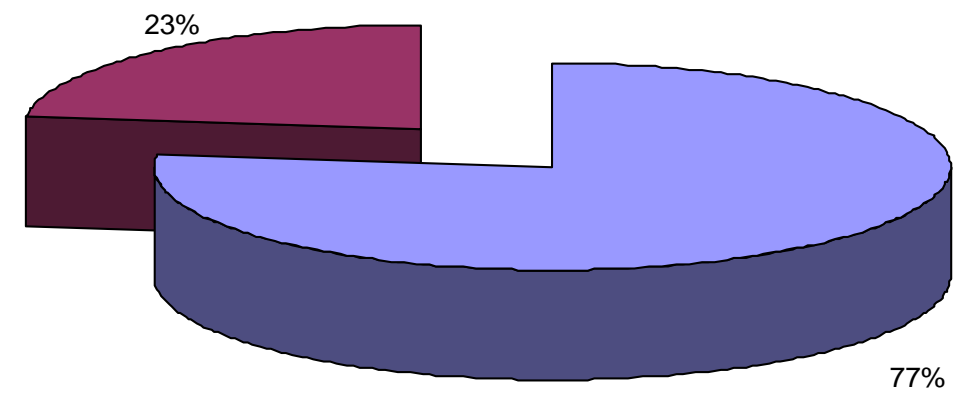

$\square$ Large Scaleu Small \& Medium Scale

Figure 1. "Different sizes of the Indian industries responded".

Figure 2 illustrates the rate of response from different key sectors of the Indian industries. As appears from the figure that manufacturing sector is on the top in implementing Six Sigma with $69 \%$ contribution. IT (Information Technology) industries are second to manufacturing sector in implementing Six Sigma with 15\% contribution. Manufacturing and service combined and others are equal in implementing Six Sigma, both at a low contribution of mere $8 \%$.

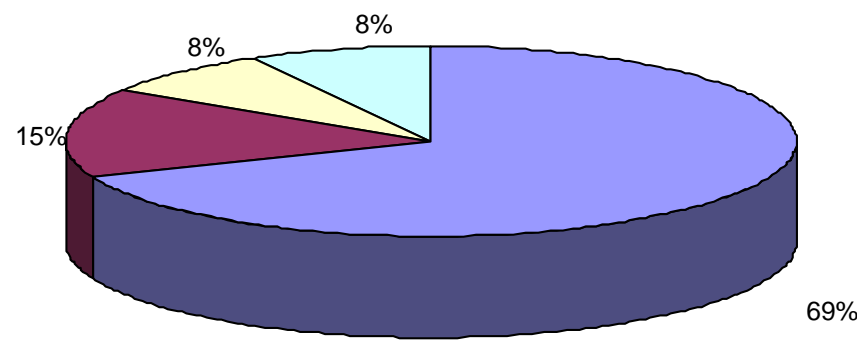

$\square$ Manufacturing

口IT

$\square$ Manufacturing \% Services

$\square$ Others

Figure 2. "Different sectors of the Indian industries responded". 


\subsection{Preliminary analysis}

Preliminary analysis illustrates an overall result regarding benefits drawn by Indian industries as a whole. The respondents were asked to rate their experience of benefits gained from Six Sigma programme in the scale of 1 to 5 ( $1=$ no benefit, 2 = some benefit, $3=$ significant benefit, $4=$ very significant benefit and $5=$ crucial benefit). Table 1 illustrates these benefiting criteria with average rating by Indian industries.

As evident from table majority of the Indian industries had reported cost reduction as the prime benefit of Six Sigma improvement drive followed by reduction in process variability, increase in profitability, reduction in cycle time and customer complaints. The top five benefiting criteria as experienced by Indian industries are listed as below with their descending order of importance.

- Reduction of costs

- Reduction of variability of process

- Increase in profitability

- Reduction of cycle time and Reduction of customer complaints (both with equal rating of importance)

- Reduction of scrap rate

The benefiting criteria, "Entry into new markets", got the least average score of importance ( 2.455 out of 5 ). But looking at the total picture, Indian industries got benefited on all the 17 criteria and overall average score is 3.214 , that is, slightly more than significant benefit level. This is the strong indication of capability of Six Sigma quality engineering and management improvement drive to bring overall operational excellence in the Indian industries.

\subsection{Analysis on benefits drawn from Six Sigma implementation by large and medium scale industries}

To create better understanding of Six Sigma benefits for large and medium scale industries, all the benefits were listed in descending order of their average rating separately for large and medium scale industries. Tables 2 and 3 illustrate the 
mean ratings of Six Sigma benefits in their descending order by large and medium scale industries respectively.

\begin{tabular}{|c|l|c|}
\hline Sr. No. & Benefit & $\begin{array}{c}\text { Mean } \\
\text { Rating }\end{array}$ \\
\hline 1 & Reduction of costs & 3.625 \\
\hline 2 & Reduction of customer complaints & 3.500 \\
\hline 3 & Increase in productivity & 3.500 \\
\hline 4 & Reduction of cycle time & 3.375 \\
\hline 5 & Reduction of delivery time & 3.375 \\
\hline 6 & Reduction of variability of process & 3.375 \\
\hline 7 & Reduced need for checking/inspection & 3.375 \\
\hline 8 & Reduction of scrap rate & 3.250 \\
\hline 9 & Increase in profitability & 3.125 \\
\hline 10 & Improved sales & 3.125 \\
\hline 11 & New product development & 3.000 \\
\hline 12 & Improved attitude of employees towards quality and & 3.000 \\
\hline 13 & problem solving & 2.875 \\
\hline 14 & Improvement in company image & 2.875 \\
\hline 15 & Increase in overseas sales & 2.875 \\
\hline 16 & Improved attitude of top management towards quality & 2.875 \\
\hline 17 & and problem solving & 2.750 \\
\hline
\end{tabular}

(Scale: $1=$ no benefit, $2=$ some benefit, $3=$ significant benefit, $4=$ very significant benefit and $5=$ crucial benefit)

Table 2. "Benefits gained due to Six Sigma implementation by large scale industries (Mean ratings arranged in descending order of benefit)".

\begin{tabular}{|c|l|c|}
\hline Sr. No. & Benefit & $\begin{array}{c}\text { Mean } \\
\text { Rating }\end{array}$ \\
\hline 1 & Increase in profitability & 4.667 \\
\hline 2 & Increase in productivity & 4.333 \\
\hline 3 & Reduction of costs & 4.333 \\
\hline 4 & Reduction of scrap rate & 4.000 \\
\hline 5 & Reduction of variability of process & 4.000 \\
\hline 6 & Reduction of cycle time & 3.667 \\
\hline 7 & Reduction of customer complaints & 3.333 \\
\hline 8 & Improved sales & 3.333 \\
\hline 9 & Improvement in company image & 3.333 \\
\hline 10 & Improvement in employees morale & 3.333 \\
\hline 11 & New product development & 3.333 \\
\hline 12 & Improved attitude of top management towards quality & 3.333 \\
\hline 13 & and problem solving & 3.000 \\
\hline 14 & Reduction of delivery time & 3.000 \\
\hline 15 & Reduced need for checking/inspection & 3.000 \\
\hline 16 & Improved attitude of employees towards quality and & 2.000 \\
\hline 17 & Increase in overseas sales & 1.333 \\
\hline
\end{tabular}

(Scale: $1=$ no benefit, $2=$ some benefit, $3=$ significant benefit, $4=$ very significant benefit and $5=$ crucial benefit)

Table 3. "Benefits gained due to Six Sigma implementation by medium scale industries (Mean ratings arranged in descending order of benefit)". 
As evident from the tables 2 and 3 large scale industries have derived the Six Sigma benefits in the range of some benefit to significant benefit, as all the 17 benefiting criteria are rated from lowest of 2.750 to the highest of 3.625. While for medium scale industries this range is much wider with lowest of 1.333 to highest of 4.667 , that means, almost covering the entire spectrum of no benefit to crucial benefit.

The largest benefit drawn from Six Sigma implementation by large scale industries is "reduction in costs", whereas it is "increase in profitability" for medium scale industries.

\subsection{Detailed analysis}

Hypothesis testing (One - way ANOVA - F Ratio Analysis) for different scales of the industries

In this case, we have null and alternative hypotheses:

- Null Hypothesis $\left(\mathrm{H}_{0}\right)$ : There is no difference in benefits obtained from Six Sigma implementation by large and medium scale industries.

- Alternative Hypothesis $\left(\mathrm{H}_{\mathrm{A}}\right)$ : There is difference in benefits obtained from Six Sigma implementation by large and medium scale industries.

Following inferences were drawn based on the ANOVA calculations.

- For the two benefits, "increase in productivity" and "increase in profitability", calculated $F$ ratio is greater than critical $F$ value of 4.26 with degree of freedom $(1,24)$ and hence null hypothesis for them is rejected. Further, since $p$-value for all of them is also less than the significance level (0.05), with this also the null hypothesis is rejected.

- For rest of the benefits, calculated $F$ ratio is less than critical value of 4.26 with degree of freedom $(1,24)$ and hence null hypothesis for them is accepted. Further, since $p$-value for all of them is also greater than the significance level $(0.05)$, with this also the null hypothesis is accepted.

The ANOVA calculations reveal that for the two benefiting criteria, "increase in productivity" and "increase in profitability", large and medium scale industries are 
differing. And for rest of the criteria, benefits obtained by large and medium scale industries are the same. But as evident from the mean rating tables 2 and 3, the factor "increase in productivity" is having mean rating of 3.5 for large scale industries and 4.33 for medium scale industries respectively. That means large and medium scale industries are more or less equally benefited by Six Sigma programme on productivity improvement aspect. So, based on mean rating on benefits obtained, even though the null hypothesis is rejected, it is accepted that the benefits obtained by Six Sigma implementation on productivity improvement is same for the large and medium scale industries.

The same comments as above cannot be made for the benefit criteria of "increase in profitability" because there is larger difference in mean rating for this factor between large and medium scale industries. The mean rating for large scale industries for this factor is 3.125 and the same for medium scale industries is 4.667.

Chi-Square Test (Different Scales of the Industries)

\begin{tabular}{|c|l|c|c|c|c|}
\hline No. & Benefit & $\begin{array}{l}\text { Pearson } \\
\text { Chi-Square }\end{array}$ & df & Significance & $\begin{array}{l}\text { Critical Value for } \\
\text { Significance level } \\
\text { 0.01 }\end{array}$ \\
\hline 1 & Reduction of scrap rate & 17.550 & 5 & 0.004 & 15.086 \\
\hline 2 & Reduction of cycle time & 4.969 & 4 & 0.291 & 13.277 \\
\hline 3 & Reduction of delivery time & 12.480 & 5 & 0.029 & 15.086 \\
\hline 4 & Reduction of customer complaints & 7.222 & 4 & 0.125 & 13.277 \\
\hline 5 & Increase in productivity & 5.344 & 4 & 0.254 & 13.277 \\
\hline 6 & Reduction of variability of process & 26.000 & 4 & 0.000 & 13.277 \\
\hline 7 & $\begin{array}{l}\text { Reduced need for } \\
\text { checking/inspection }\end{array}$ & 7.222 & 5 & 0.205 & 15.086 \\
\hline 8 & Reduction of costs & 4.969 & 4 & 0.291 & 13.277 \\
\hline 9 & Increase in profitability & 16.987 & 4 & 0.002 & 13.277 \\
\hline 10 & Improved sales & 17.550 & 5 & 0.004 & 15.086 \\
\hline 11 & Improvement in company image & 16.987 & 4 & 0.002 & 13.277 \\
\hline 12 & $\begin{array}{l}\text { Improvement in employees } \\
\text { morale }\end{array}$ & 9.100 & 5 & 0.105 & 15.086 \\
\hline 13 & Increase in overseas sales & 12.856 & 4 & 0.012 & 13.277 \\
\hline 14 & New product development & 4.969 & 5 & 0.420 & 15.086 \\
\hline 15 & Entry into new markets & 18.489 & 4 & 0.001 & 13.277 \\
\hline 16 & $\begin{array}{l}\text { Improved attitude of employees } \\
\text { towards quality and problem } \\
\text { solving }\end{array}$ & 1.964 & 3 & 0.580 & 11.345 \\
\hline 17 & $\begin{array}{l}\text { Improved attitude of top } \\
\text { management towards quality and } \\
\text { problem solving }\end{array}$ & 4.406 & 4 & 0.354 & 13.277 \\
\hline
\end{tabular}

Table 4. "Pearson Chi-Square Values (Six Sigma benefits achieved by large and medium scale industries)". 
For further verification of the above results, Chi-square test was carried out calculating Pearson Chi-Square value with significance level 0.01 . The calculated values and corresponding critical values obtained from the standard statistical table are illustrated in table 4.

The cases where calculated value is less than critical value of $\mathbf{x}^{\mathbf{2}}$, the null hypothesis is accepted. The null hypothesis is "there is no difference in benefits achieved by Six Sigma programme in large and medium scale industries". Thus, the aspects on which same benefits drawn by large and medium scale industries from Six Sigma programme are as below.

- Reduction of cycle time

- Reduction of delivery time

- Reduction of customer complaints

- Increase in productivity

- Reduced need for checking/inspection

- Reduction of costs

- Improvement in employees morale

- Increase in overseas sales

- New product development

- Improved attitude of employees towards quality and problem solving

- Improved attitude of top management towards quality and problem solving

Comparing the calculated values from table 5 with the critical $\mathbf{x}^{2}$ value, null hypothesis is rejected for the following cases since calculated values are greater than critical values.

- Reduction of scrap rate

- Reduction of variability of process 
- Increase in profitability

- Improved sales

- Improvement in company image

- Entry into new markets

ANOVA is a parametric test which is considered more powerful than nonparametric test such as Chi-square test. However, Chi-square test is the most widely used nonparametric test. So here, the common results from both the tests are considered the final results of the analysis. Thus, except in two benefits, "increase in productivity" and "increase in profitability", it can be concluded that benefits drawn by large and medium scale industries are more or less same on all other aspect.

Analysis on benefits drawn from Six Sigma implementation by different industrial sectors

An analysis similar to what carried for large and medium scale industries regarding benefits drawn from Six Sigma programme was also performed for different industrial sectors. Table 5 illustrates mean score of benefiting criteria for different sectors in their ascending order of benefits obtained. The benefits obtained are rated by them in the scale of 1 to 5 ( $1=$ No benefit, $2=$ Some benefit, $3=$ Significant benefit, $4=$ Very significant benefit, $5=$ Crucial benefit).

As evident from the table 5, the prominent benefiting criteria are different for all the sectors, as listed below.

For manufacturing sector the top most benefiting criteria are...

- Reduction of customer complaints,

- Increase in productivity,

- Reduction of variability of process

- Reduction of costs

For manufacturing and service sector the top most benefits are... 
- Reduction of costs

- Increase in profitability

\begin{tabular}{|c|c|c|c|c|}
\hline No. & Manufacturing & $\begin{array}{l}\text { Manufacturing \& } \\
\text { Service }\end{array}$ & IT & Others \\
\hline 1 & $\begin{array}{l}\text { Reduction of } \\
\text { customer complaints } \\
\text { (3.11) }\end{array}$ & $\begin{array}{l}\text { Reduction of costs } \\
\text { (5) }\end{array}$ & $\begin{array}{l}\text { Reduction of delivery } \\
\text { time (3.5) }\end{array}$ & $\begin{array}{l}\text { New product } \\
\text { development (4) }\end{array}$ \\
\hline 2 & $\begin{array}{l}\text { Increase in } \\
\text { productivity (3.11) }\end{array}$ & $\begin{array}{l}\text { Increase in } \\
\text { profitability (5) }\end{array}$ & $\begin{array}{l}\text { Reduction of costs } \\
(3.5)\end{array}$ & $\begin{array}{l}\text { Reduction of scrap } \\
\text { rate (3) }\end{array}$ \\
\hline 3 & $\begin{array}{l}\text { Reduction of } \\
\text { variability of process } \\
(3.11)\end{array}$ & $\begin{array}{l}\text { Reduction of scrap } \\
\text { rate }(4)\end{array}$ & $\begin{array}{l}\text { Reduction of cycle } \\
\text { time (3) }\end{array}$ & $\begin{array}{l}\text { Reduction of cycle } \\
\text { time (3) }\end{array}$ \\
\hline 4 & $\begin{array}{l}\text { Reduction of costs } \\
(3.11)\end{array}$ & $\begin{array}{l}\text { Reduction of cycle } \\
\text { time (4) }\end{array}$ & $\begin{array}{l}\text { Increase in } \\
\text { productivity ( } 3 \text { ) }\end{array}$ & $\begin{array}{l}\text { Reduction of } \\
\text { customer complaints } \\
\text { (3) }\end{array}$ \\
\hline 5 & $\begin{array}{l}\text { Reduction of scrap } \\
\text { rate }(3)\end{array}$ & $\begin{array}{l}\text { Increase in } \\
\text { productivity (4) }\end{array}$ & $\begin{array}{l}\text { Increase in } \\
\text { profitability (3) }\end{array}$ & $\begin{array}{l}\text { Increase in } \\
\text { productivity (3) }\end{array}$ \\
\hline 6 & $\begin{array}{l}\text { Reduced need for } \\
\text { checking/inspection } \\
\text { (3) }\end{array}$ & $\begin{array}{l}\text { Reduction of } \\
\text { variability of process } \\
(4)\end{array}$ & $\begin{array}{l}\text { Reduction of } \\
\text { customer complaints } \\
(2.5)\end{array}$ & $\begin{array}{l}\text { Reduced need for } \\
\text { checking/inspection } \\
\text { (3) }\end{array}$ \\
\hline 7 & $\begin{array}{l}\text { Reduction of delivery } \\
\text { time }(2.89)\end{array}$ & $\begin{array}{l}\text { New product } \\
\text { development (4) }\end{array}$ & $\begin{array}{l}\text { Reduction of } \\
\text { variability of process } \\
(2.5)\end{array}$ & $\begin{array}{l}\text { Reduction of costs } \\
\text { (3) }\end{array}$ \\
\hline 8 & $\begin{array}{l}\text { Increase in } \\
\text { profitability (2.89) }\end{array}$ & I mproved sales (3) & $\begin{array}{l}\text { Entry into new } \\
\text { markets }(2.5)\end{array}$ & $\begin{array}{l}\text { Increase in overseas } \\
\text { sales (3) }\end{array}$ \\
\hline 9 & $\begin{array}{l}\text { Improved sales } \\
(2.89)\end{array}$ & $\begin{array}{l}\text { Improvement in } \\
\text { company image (3) }\end{array}$ & $\begin{array}{l}\text { I mproved attitude of } \\
\text { employees towards } \\
\text { quality and problem } \\
\text { solving }(2.5)\end{array}$ & $\begin{array}{l}\text { Entry into new } \\
\text { markets (3) }\end{array}$ \\
\hline 10 & $\begin{array}{l}\text { Reduction of cycle } \\
\text { time }(2.78)\end{array}$ & $\begin{array}{l}\text { Improvement in } \\
\text { employees morale } \\
\text { (3) }\end{array}$ & $\begin{array}{l}\text { I mproved attitude of } \\
\text { top management } \\
\text { towards quality and } \\
\text { problem solving }(2.5)\end{array}$ & $\begin{array}{l}\text { I mproved attitude of } \\
\text { employees towards } \\
\text { quality and problem } \\
\text { solving (3) }\end{array}$ \\
\hline 11 & $\begin{array}{l}\text { Improvement in } \\
\text { company image } \\
(2.78)\end{array}$ & $\begin{array}{l}\text { I mproved attitude of } \\
\text { employees towards } \\
\text { quality and problem } \\
\text { solving (3) }\end{array}$ & $\begin{array}{l}\text { Reduced need for } \\
\text { checking/inspection } \\
(2)\end{array}$ & $\begin{array}{l}\text { I mproved attitude of } \\
\text { top management } \\
\text { towards quality and } \\
\text { problem solving (3) }\end{array}$ \\
\hline 12 & $\begin{array}{l}\text { I mproved attitude of } \\
\text { top management } \\
\text { towards quality and } \\
\text { problem solving } \\
(2.78)\end{array}$ & $\begin{array}{l}\text { I mproved attitude of } \\
\text { top management } \\
\text { towards quality and } \\
\text { problem solving (3) }\end{array}$ & I mproved sales ( 2 ) & $\begin{array}{l}\text { Reduction of delivery } \\
\text { time (2) }\end{array}$ \\
\hline 13 & $\begin{array}{l}\text { Improvement in } \\
\text { employees morale } \\
(2.67)\end{array}$ & $\begin{array}{l}\text { Reduction of } \\
\text { customer complaints } \\
\text { (2) }\end{array}$ & $\begin{array}{l}\text { Reduction of scrap } \\
\text { rate }(1.5)\end{array}$ & $\begin{array}{l}\text { Reduction of } \\
\text { variability of process } \\
\text { (2) }\end{array}$ \\
\hline 14 & $\begin{array}{l}\text { New product } \\
\text { development (2.67) }\end{array}$ & $\begin{array}{l}\text { Reduction of delivery } \\
\text { time (1) }\end{array}$ & $\begin{array}{l}\text { Improvement in } \\
\text { company image (1.5) }\end{array}$ & $\begin{array}{l}\text { Increase in } \\
\text { profitability (2) }\end{array}$ \\
\hline 15 & $\begin{array}{l}\text { I mproved attitude of } \\
\text { employees towards } \\
\text { quality and problem } \\
\text { solving }(2.44)\end{array}$ & $\begin{array}{l}\text { Reduced need for } \\
\text { checking/inspection } \\
\text { (1) }\end{array}$ & $\begin{array}{l}\text { I mprovement in } \\
\text { employees morale } \\
\text { (1.5) }\end{array}$ & Improved sales (2) \\
\hline 16 & $\begin{array}{l}\text { Increase in overseas } \\
\text { sales }(2.22)\end{array}$ & $\begin{array}{l}\text { Increase in overseas } \\
\text { sales (1) }\end{array}$ & $\begin{array}{l}\text { Increase in overseas } \\
\text { sales (1.5) }\end{array}$ & $\begin{array}{l}\text { Improvement in } \\
\text { company image (2) }\end{array}$ \\
\hline 17 & $\begin{array}{l}\text { Entry into new } \\
\text { markets ( } 2 \text { ) }\end{array}$ & $\begin{array}{l}\text { Entry into new } \\
\text { markets ( } 1 \text { ) }\end{array}$ & $\begin{array}{l}\text { New product } \\
\text { development (1.5) }\end{array}$ & $\begin{array}{l}\text { Improvement in } \\
\text { employees morale } \\
\text { ( } 2 \text { ) }\end{array}$ \\
\hline
\end{tabular}

Table 5. "Benefits drawn from Six Sigma implementation in different industrial sectors (in their descending order with mean rating value in the bracket)". 
For IT industries the most prominent benefits drawn by Six Sigma are...

- Reduction of delivery time

- Reduction of costs

For others the most important benefit from Six Sigma is in new product development process. Looking at the mean score of the benefits drawn as in table 5, it appears that the benefits drawn from Six Sigma implementation by different sectors of the industries are different in attribute as well as in the magnitude of the benefits drawn.

Hypothesis Testing (One - way ANOVA - F Ratio Analysis) for different industrial sectors

To have in-depth analysis of similarity of benefits drawn from Six Sigma programme by different sectors of industries, one way ANOVA was performed with following hypothesis.

- Null Hypothesis $\left(\mathrm{H}_{\mathrm{O}}\right)$ : There is no difference in benefits obtained from Six Sigma implementation by different industrial sectors.

- Alternative Hypothesis $\left(H_{A}\right)$ : There is difference in benefits obtained from Six Sigma implementation by different industrial sectors.

It appears from the ANOVA calculations that calculated $F$ ratio for all the 17 benefiting aspect are less than critical value of 3.05 with degree of freedom $(3,22)$ and hence null hypothesis for all of them is accepted. Further, since p-value for all of them is also greater than the significance level $(0.05)$, with this also the null hypothesis is accepted.

So, based on above analysis it can be concluded that there is no difference among different industrial sectors in the benefits drawn from Six Sigma implementation in their organizations.

\section{Chi-Square test (different industrial sectors)}

The above ANOVA results are having some contradictions with the conclusions drawn from the mean ratings obtained for all the sectors as in table 5 . Thus, for further verification of the above results, Chi-square test was carried out calculating 
Pearson Chi-Square value with significance level 0.01 . The calculated values and corresponding critical values obtained from the standard statistical table are illustrated in table 6.

\begin{tabular}{|c|l|c|c|c|c|}
\hline No. & Benefit & $\begin{array}{c}\text { Pearson } \\
\text { Chi-Square }\end{array}$ & df & Significance & $\begin{array}{c}\text { Critical Value for } \\
\text { Significance level } \\
\mathbf{0 . 0 1}\end{array}$ \\
\hline 1 & Reduction of scrap rate & 33.944 & 15 & 0.003 & 30.578 \\
\hline 2 & Reduction of cycle time & 16.130 & 12 & 0.185 & 26.217 \\
\hline 3 & Reduction of delivery time & 42.900 & 15 & 0.000 & 30.578 \\
\hline 4 & Reduction of customer complaints & 30.574 & 12 & 0.002 & 26.217 \\
\hline 5 & Increase in productivity & 33.704 & 12 & 0.001 & 26.217 \\
\hline 6 & Reduction of variability of process & 22.870 & 12 & 0.029 & 26.217 \\
\hline 7 & $\begin{array}{l}\text { Reduced need for } \\
\text { checking/inspection }\end{array}$ & 30.574 & 15 & 0.010 & 30.578 \\
\hline 8 & Reduction of costs & 26.530 & 12 & 0.009 & 26.217 \\
\hline 9 & Increase in profitability & 22.919 & 12 & 0.028 & 26.217 \\
\hline 10 & Improved sales & 28.229 & 12 & 0.004 & 26.217 \\
\hline 11 & Improvement in company image & 35.630 & 12 & 0.000 & 26.217 \\
\hline 12 & $\begin{array}{l}\text { Improvement in employees } \\
\text { morale }\end{array}$ & 28.407 & 15 & 0.019 & 30.578 \\
\hline 13 & Increase in overseas sales & 20.463 & 12 & 0.059 & 26.217 \\
\hline 14 & New product development & 22.341 & 15 & 0.099 & 30.578 \\
\hline 15 & Entry into new markets & 18.296 & 12 & 0.107 & 26.217 \\
\hline 16 & $\begin{array}{l}\text { Improved attitude of employees } \\
\text { towards quality and problem } \\
\text { solving }\end{array}$ & 11.941 & 9 & 0.217 & 21.666 \\
\hline 17 & $\begin{array}{l}\text { Improved attitude of top } \\
\text { management towards quality and } \\
\text { problem solving }\end{array}$ & 16.491 & 12 & 0.170 & 26.217 \\
\hline
\end{tabular}

Table 6. "Pearson Chi-Square Values (Six Sigma benefits achieved by different industrial sectors)."

The cases where calculated value is less than critical value of $\mathbf{x}^{\mathbf{2}}$, the null hypothesis is accepted. The null hypothesis is "there is no difference in benefits achieved by Six Sigma programme in different industrial sectors".

Comparing the calculated values from table 6 with the critical $\mathbf{x}^{2}$ value, null hypothesis is rejected for the following cases since calculated values are greater than critical values. That means benefits drawn from Six Sigma are not the same in different industrial sectors for following criteria.

- Reduction of scrap rate

- Reduction of delivery time

- Reduction of customer complaints

- Increase in productivity 
- Improved sales

- Improvement in company image

For rest of the benefiting criteria it is concluded that benefits drawn from Six Sigma programme is the same in different industrial sectors. As discussed above ANOVA is more powerful test, but we cannot ignore the results of Chi-square test too, hence it can be fairly concluded that except for above listed criteria benefits drawn from Six Sigma programme is the same in different industrial sectors.

\section{Concluding remarks}

\subsection{Theoretical implications}

Six Sigma has already emerged as one of the most effective business strategies in the large organizations, worldwide. After its conception at Motorola, many success stories were charted by a number of multinationals. Indian industries have already started recognizing the strengths of Six Sigma as a breakthrough improvements strategy, which can bring overall operational excellence for global competence. As a part of the drive to ascertain the status of Six Sigma among Indian industries as a whole, this study was taken up to highlight the benefits gain by Indian industries through Six Sigma.

The study was aimed at finding out the similarity or otherwise of the benefits drawn by different sizes and sectors of Indian industries by Six Sigma implementation. As revealed from the study that with some exceptions, different sizes as well as different sectors of the Indian industries have achieved more or less similar benefits from Six Sigma. However, above analysis revealed few benefiting criteria where the experiences of different sizes and sectors of the Indian industries are not the same. The criteria where the benefits drawn from Six Sigma programme is not the same for large and medium scale industries as well as for different industrial sectors are listed as below.

- Reduction of scrap rate

- Improved sales

- Improvement in company image 


\subsection{Managerial and practical implications}

As a whole, this study provided a comprehensive picture regarding benefits being drawn by Indian industries through Six Sigma improvement drive till date. The study provided an insight into what kind of benefits Indian industries are gaining from Six Sigma. This can help other industries, who have yet not experimented with Six Sigma, to become more focused regarding their expectations from this improvement drive. Based on the analysis of this study, individual industry based on their size and type of operations can expect some specific benefits from Six Sigma implementation. The Six Sigma programme can be initiated with some specific benefits in view based on industry operations.

\subsection{Limitations of the study and future scope of research}

As the case with any research study focused on survey analysis, the major limitation of this study also was about getting the required number of responses from the industries. Since the study was targeting entire Indian industries, the questionnaire was sent to the industries across the country. The personal interview with company executives involved in Six Sigma implementation could not be undertaken. However, the 17 benefiting criteria selected were capable enough to extract maximum possible details from the concerns regarding overall benefits drawn by them through Six Sigma implementation. The data collected were tested for normality and found appropriate for further analysis.

Since the study was aimed at analyzing the benefits drawn by Indian industries as a whole by Six Sigma implementation, further detailed analysis could not be performed. Future research can aim at individual case analysis of the different scales and sectors of industries regarding drawing a link between their objectives of implementing Six Sigma and real benefits drawn. Furthers, a comparative analysis of Six Sigma benefits gained by different countries can also be taken up.

\section{References}

Antony, J., Kumar, M., \& Madu, C. N. (2005). Six Sigma in small and medium sized UK manufacturing enterprises: Some empirical observations. International Journal of Quality and Reliability Management, 22(8), 860-874. 
Carey, B. (2007). Business Process Reengineering in a Six Sigma World. Retrieved May, 2007 from www.iSixSigma.com/library/content/.

Desai, D. A. (2006). Improving customer delivery commitments the Six Sigma way: case study of an Indian small scale industry. International Journal of Six Sigma and Competitive Advantage, 2(1), 23-47.

Desai, D. A. (2008). Improving productivity and profitability through Six Sigma: experience of a Small-scale jobbing industry. International J ournal of Productivity and Quality Management, 3(3), 290-310.

Eckes, G. (2001). The Six Sigma Revolution, How General Electric and Others Turned Process Into Profits. USA: John Wiley \& Sons, Inc.

Export-Import Bank of India (EXIM Bank). (2005). Export Performance of Small and Medium Enterprises in India, Research Brief, 18(October), SP3-1-SP3-4.

Franken, B. (2007). How to Explain Six Sigma by Using the Profit Triangle. Retrieved May, 2007 from www.iSixSigma.com/library/content/.

Khanna, V. K., Vrat, P., Sahay, B. S., \& Shankar R. (2002). Six Sigma in Indian Automobile Sector. Productivity, 43(2), 208-214.

Kumar, V., Garg, D., \& Mehta, N. P. (2002). JIT/TQM in Indian Industries. Productivity, 43(2), 215-224.

Linderman, K., Schroeder, R. G., Zaheer, S., \& Choo, A. S. (2003). Six Sigma: a goal-theoretic perspective. J ournal of Operations Management, 21, 193-203.

Magnusson, K., Kroslid, D., \& Bergman, B. (2003). Six Sigma - The Pragmatic Approach. Scandinavia: Lund, Studentlitteratur.

Park, S. H. (2002). Six Sigma for productivity improvement: Korean business corporations. Productivity, 43(2), 173-183.

Verma, R. (2005). Performance of Small-Scale Industries (Pre and Post Reform Period). Udyog Pragati, 29(2), 35-41. 
Voelkel, J. G. (2002). Something's Missing - An education in statistical methods will make employees more valuable to Six Sigma corporations. Quality Progress, (May), 98-101.

Wright, J. N., \& Basu, R. (2008). Project management and Six Sigma: obtaining a fit. International J ournal of Six Sigma and Competitive Advantage, 4(1), 81-94.

Zucker, D. (2007). Integrating Project Management into a Six Sigma System.

Retrieved August, 2007 from http://www.isixsigma.com/library/content/.

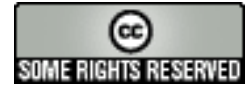

\footnotetext{
Article's contents are provided on a Attribution-Non Commercial 3.0 Creative commons license. Readers are allowed to copy, distribute and communicate article's contents, provided the author's and Journal of Industrial Engineering and Management's names are included. It must not be used for commercial purposes. To see the complete license contents, please visit http://creativecommons.org/licenses/by-nc/3.0/.
} 